УДК 331.55-054.7-044.332(571.51)

ББК 65.240.7(2P-4Крн)

\title{
АДАПТАЦИЯ МИГРАНТОВ КАК ФАКТОР РАЗВИТИЯ ЭКОНОМИКИ КРАСНОЯРСКОГО КРАЯ
}

На примере Международной научной конференции 2017 г. в Сибирском федеральном университете рассматривается проблема адаптации мигрантов в Красноярском крае и их влияние на экономику региона.

Ключевые слова: адаптация мигрантов, экономика, Красноярский край.

A.V. ZADORIN

\section{ADAPTATION OF MIGRANTS AS A DEVELOPMENT FACTOR OF KRASNOYARSK REGION'S ECONOMY}

On the example of the International scientific conference 2017 in the Siberian Federal University the problem of adaptation of migrants in the Krasnoyarsk region and their impact on the economy of the region is considered.

Keywords: adaptation of migrants, economy, Krasnoyarsk region.

Согласно прогнозу Росстата, сделанному в 2015 г., численность населения России в 2016-2030 гг. возрастет на 0,9 млн чел. Однако с экономической точки зрения ситуация ухудшится, поскольку россиян трудоспособного возраста станет меньше на 5 млн чел. И хотя в Красноярском крае пока еще сохраняется естественный прирост населения, общероссийских тенденций региону не избежать [4; 5].

В последнее время важнейшим ресурсом сдерживания депопуляции в России становится миграция. Низкий уровень рождаемости, безусловно, отражается на состоянии народного хозяйства. Складывается опасная ситуация, когда за счет привлечения иностранной рабочей силы поддерживается потенциал экономического развития страны и геополитическая стабильность отдельных регионов.

События последних лет лишь подтверждают эту горькую истину. И события не только из экономической области, но и в научном сообществе. Одним из таких примеров стала Международная научная конференция «Специфика этнических миграционных процессов на территории Центральной Сибири в XX-XXI вв.: опыт и перспективы», которая проходила с 30 ноября по 2 декабря 2017 г. в Сибирском федеральном университете [8]. (Материалы конференции вышли в свет 24 мая 2018 г.). Ее обзор касательно заявленной тематики и будет представлен в данной статье. 
Исследователи могут высказывать разные точки зрения, но как показывает практика, последнее слово остается за представителями власти. Наглядный тому пример - пленарное выступление Р.Г. Рафикова, заместителя начальника управления общественных связей Губернатора Красноярского края. Впрочем, в данном случае административную должность занимает ученый (Р.Г. Рафиков - кандидат исторических наук). Как бы там ни было, суть его доклада заключается в невозможности обойтись без мигрантов, а потому их необходимо адаптировать и интегрировать. Собственно такова и тема: «Адаптация и интеграция мигрантов: региональный опыт Красноярского края». Поскольку данный доклад не вошел в сборник материалов конференции, имеет смысл задержать на нем внимание.

Красноярский край представлен широкой палитрой национальностей и культов. Помимо русских в крае проживают представители 158 национальностей (290 тыс. чел. или 10,5 \%), действуют 330 религиозных организаций. Происходит постоянный прирост мигрантов из числа иностранных граждан, преобладают мигранты из Средней Азии.

И после такой справочной информации в смысле «Красноярский край большой, всем места хватит» последовал шокирующий пример (во всяком случае, для меня). В 2016 г. на учет было поставлено 180 тыс. иностранных граждан, 2/3 которых являлись выходцами из Средней Азии: из Таджикистана (29 \%), Узбекистана (20\%) и Кыргызстана (14 \%). Подобная картина повторилась и в 2017 г. Много это или мало 180 тыс.? Такая численность сопоставима с населением Норильска, или двух городов вроде Канска!

В докладе прозвучала еще одна неприятная тенденция: трудовые мигранты рассредоточены неравномерно. Наибольшая их концентрация отмечается в крупных городах и прилегающих к ним районах. Вернее будет сказать, в Красноярске и прилегающих к нему районах, что неоднократно отмечалось журналистами и исследователями, в том числе автором данной статьи [6; 7]. Как говорится, рыба ищет, где глубже. В мегаполисе легче найти работу и трудоустроиться, не имея высшего и профессионального специального образования; в них также лучше развита социальная инфраструктура.

Не является откровением, что большое количество мигрантов создает угрозу для этнокультурной безопасности принимающей территории. Этнические мигранты склонны к созданию объединений, диаспор, и, таким образом, несмотря на нахождение на иной территории, они не включены в культуру этой территории и действуют в рамках закрытого национального сообщества. Разумеется, в администрации Красноярского края это понимают и принимают меры. Одно из главных направлений адаптации мигрантов - создание развернутой сети переговорных площадок, как то: Дом дружбы народов Красноярского края, Красноярский межнациональный культурный центр при Дворце Труда и Согласия и др. 
Реализация национальной политики выливается в немалые суммы. Вот пример из того же доклада Р.Г. Рафикова. Расходы из краевого бюджета на государственную программу «Укрепление единства российской нации и этнокультурное развитие народов Красноярского края» в 2015-2017 гг. составили 240 млн р. Плюс 39 млн р. федеральных субсидий за 2016-2017 гг. Поскольку ресурсы ограничены, средства на адаптацию мигрантов отрываются от других социальных программ. Толерантность в принципе обходится дорого. Как отмечал П.Дж. Бьюкенен в книге «Смерть Запада» (2003), в Дании 33 \% гражданского бюджета в 2000 г. шло на соцзащиту иммигрантов, составлявших 4 \% населения страны [2, с. 287]. Конечно, ситуацию в Европе можно назвать крайностью, но пример впечатляет.

Безусловно, проблема обеспечения прав мигранта на достоинство крайне актуальна. Неоспоримо и то, что государство не должно игнорировать эту тему, так как она имеет огромное значение для «защиты прав и свобод человека и гражданина, основ конституционного строя, обеспечения целостности и безопасности РФ» [1]. Однако ограничительные меры могут еще более усугубить ситуацию. В частности, высказываются предложения за использование экономических рычагов для снижения потока трудовых мигрантов [9]. Мысли такие: снизится частота взаимодействий между представителями местного населения и мигрантами градус общественных трений несколько остынет. Очевидно, что уменьшение количества мигрантов также снизит количество преступлений, совершаемых ими.

Однако в целом российские региональные и городские власти довольно индифферентно относятся к проблеме миграции и замещению россиян приезжими из других стран. Аналогичная ситуация наблюдается и в Красноярском крае, о чем уже говорилось выше. Между тем трудовые мигранты могут не только усиливать конкуренцию на рынке труда и тем самым порождать конфликтные ситуации, но также и маргинализироваться, опускаться на дно жизни. Маргиналы не участвуют в трудовом процессе, не выполняют общественных функций. Это обстоятельство также создает негативный образ мигрантов в глазах местных жителей.

Тем не менее, большинство населения, как и власть, относятся к мигрантам безразлично, что показали исследования социологов. Для иллюстрации данного тезиса обратимся к двум докладам с конференции (которые тоже не вошли в сборник материалов). Первый из них - «Миграционная политика: ключевые тренды» представила Е.А. Михайлова, директор по исследованиям Всероссийского центра изучения общественного мнения (ВЦИОМ), доцент кафедры социологии и гуманитарной культуры Национального исследовательского ядерного университета «МИФИ». Сведения для исследования были получены методом телефонного опроса (CATI) по формализованной анкете 1200 чел. стар- 
ше 18 лет. География исследования включала 85 регионов в восьми федеральных округах РФ. На вопрос: «Какие чувства Вы испытываете по отношению к иностранным мигрантам, которые работают в Вашем регионе?» респонденты ответили так (было возможно несколько вариантов ответа). Безразличие - 32 \%, сочувствие - 30 \%, уважение - 17 \%. По 8 \% набрали «неприязнь» и «интерес», другие варианты назывались реже. Причем безразличие к мигрантам чаще выказывали молодые люди в возрасте 18-34 года (48 \%), а сочувствие - граждане 60 лет и старше (37\%).

Другой интересующий нас доклад назывался «Социологический подход к изучению миграционных процессов». Его автор - Д.О. Труфанов (кандидат социологических наук, доцент кафедры социологии Института педагогики, психологии и социологии Сибирского федерального университета) изучал отношение взрослого населения Красноярского края к представителям других национальностей, религий, иностранным трудовым мигрантам. Выборка производилась по полу, возрасту и территориальному размещению взрослого населения края и составила более 1000 респондентов. Использовались анкетный опрос, метод фокус-групп, глубинные интервью, экспертные интервью. Исследование Д.О. Труфанова показало, что в массовом сознании взрослого населения Красноярского края иностранные трудовые мигранты чаще всего предстают как «люди, приехавшие на заработки» $(36,8$ \%) и «дешевая рабочая сила» (28 \%). Лишь 5,6 \% респондентов назвали иностранных мигрантов «ненужными в России людьми».

В другом случае респондентам задавался вопрос: Какие чувства Вы лично испытываете по отношению к иностранным трудовым мигрантам, прибывающим в Ваш город, район? С большим отрывом лидировал ответ «Никаких особенных чувств». Так было в 2015 г. (63 \%), в 2016 г. (49 \%) и в 2017 г. (51\%).

В 2016 г. Д.О. Труфанов изучал характер восприятия иностранных трудовых мигрантов в Красноярском крае. Респондентам предлагалось согласиться или не согласиться с рядом суждений. Были получены следующие результаты (табл.).

Полученные результаты говорят о том, что взрослое население Красноярского края не против иностранных трудовых мигрантов как таковых. Однако разрешать въезд нужно только желающим интегрироваться в культуру принимающей стороны. Миграцию необходимо если не ограничивать, то жестко контролировать.

Кардинально расходится с властью позиция народа по поводу полезности мигрантов: подавляющее число респондентов не рассматривает их как фрактор экономического развития страны. Лишь 18 \% опрошенных считают, что нужно создавать условия для привлечения иностранных трудовых мигрантов. Прибытие в Россию трудовых мигрантов из стран 
ближнего зарубежья видят неизбежным только 41 \% респондентов. Кроме того, надо иметь в виду: неизбежно не значит полезно, а мириться не значит соглашаться.

\section{Характер восприятия иностранных трудовых мигрантов в Красноярском крае в 2016 г. (Д.О. Труфанов)}

\begin{tabular}{|l|r|}
\hline \multicolumn{1}{|c|}{ Суждение } & $\begin{array}{r}\text { Baриант ответа } \\
\text { «Согласен», \% }\end{array}$ \\
\hline $\begin{array}{l}\text { Нужно разрешить въезд в Россию только тем, кто знает русский язык } \\
\text { и уважает русскую культуру }\end{array}$ & 20 \\
\hline $\begin{array}{l}\text { Влияние иностранной трудовой миграции на рост преступности в } \\
\text { красноярском крае - это миф }\end{array}$ & 73 \\
\hline $\begin{array}{l}\text { Необходимо жестко контролировать приезд в Россию иностранных } \\
\text { трудовых мигрантов }\end{array}$ & 23 \\
\hline $\begin{array}{l}\text { Приезд в Россию иностранных трудовых мигрантов способствует } \\
\text { экономическому развитию страны }\end{array}$ & 44 \\
\hline $\begin{array}{l}\text { Народы, которые имеют свою историческую родину за пределами } \\
\text { России, должны уехать туда }\end{array}$ & 66 \\
\hline $\begin{array}{l}\text { Нужно создавать условия для привлечения иностранных трудовых } \\
\text { мигрантов в Россию }\end{array}$ & 41 \\
\hline $\begin{array}{l}\text { Надо ограничивать количество иностранных трудовых мигрантов } \\
\text { в Красноярском крае }\end{array}$ & 36 \\
\hline $\begin{array}{l}\text { Прибытие в Россию трудовых мигрантов из стран ближнего зарубежья } \\
\text { неизбежно, с этим нужно смириться }\end{array}$ & \\
\hline $\begin{array}{l}\text { Проживание на территории края представителей разных национально- } \\
\text { стей обогащает культуру нашего региона }\end{array}$ & \\
\hline
\end{tabular}

Итак, в связи с острой демографической ситуацией в стране наблюдается сокращение трудовых ресурсов. Основным источником их компенсации на ближайшие десятилетия станет миграция. Ввиду сокращения миграционного потенциала российских соотечественников усилится приток выходцев из стран ближнего зарубежья, в основном из Среднеазиатского региона. Это будет серьезным вызовом для автохтонного населения, если не обеспечить адаптацию и интеграцию мигрантов. Вопрос в том, как ее осуществлять. При молчаливом согласии большинства населения происходит ассимиляция этого самого населения.

Между тем власть намерена продолжать существующий курс. Данное утверждение справедливо и для высшего образования и науки. Совсем свежий пример. Недавно в Сибирском федеральном университете сменился руководитель департамента международного сотрудничества. На вопрос о планах на будущее он в частности сказал: «Иностранных студентов у нас (в СФУ. - А. З.) - почти тысяча человек, но хотелось бы значительно увеличить (курсив мой. - А. З.) их количество» [3].

Обстановка сложилась такая, что от привлечения иностранцев стало зависеть благополучие региона. В настоящее время народ терпеливо относится к ним, либо пытается не замечать. Как будет развиваться ситуация дальше - предсказать трудно. 


\section{Список использованной литературы и источников}

1. О противодействии экстремистской деятельности : федер. закон от 25 июля 2002 г. № 114-Ф3 (ред. от 23.11.2015) [Электронный ресурс] // КонсультантПлюс. - Режим доступа : http://www.consultant.ru/cons/ cgi/online.cgi?req=doc\&ba se $=$ LAW \&n=189271\&fld $=134 \& d s t=1000000001,0 \& r n d=0.9341830051626114 \# 0$

2. Бьюкенен П. Дж. Смерть Запада / П. Дж. Бьюкенен ; пер. с англ. А. Башкирова. - М. : Изд-во АСТ; СПб. : Terra Fantastica, 2004. - 444 с.

3. Ефанова В. М. 5 вопросов новым людям / В. М. Ефанова, Л. А. Кравцова, П. В. Лапо // Новая университетская жизнь. - 2019. - 15 февр. - С. 8-9.

4. Задорин А. В. Демографическая ситуация в Красноярском крае в начале XXI века: что ожидает регион в будущем? / А. В. Задорин // Ключевые инструменты организации человеческого общежития: экономика и право : сб. материалов XII Междунар. науч.-практ. конф. Киев, Лондон, 27 октября - 1 ноября 2011 г. Юридические науки, открытая секция. - Одесса, 2011. - С. 82-84.

5. Задорин А. В. Подъем рождаемости в Красноярском крае: причины и прогноз на будущее / А. В. Задорин // Иркутский историко-экономический ежегодник: 2016. - Иркутск : Изд-во БГУ, 2016. - С. 458-463.

6. Задорин А. В. Урбанизация и социальные проблемы миллионного Красноярска [Электронный ресурс] / А. В. Задорин // Седьмые Ковалевские чтения : материалы науч.-практ. конф. 15-16 ноября 2012 г. / отв. ред. Ю. В. Асочаков. - СПб., 2012. - С. 975-978. - Режим доступа : http://soc.spbu.ru/nauka/ publications/7k.pdf

7. Задорин А. В. Поселенческая структура Красноярского края в 19702010 гг.: проблемы совершенствования / А. В. Задорин, М. Д. Северьянов // Известия Алтайского государственного университета. Исторические науки и археология. - 2016. — № 4. - С. 71-75.

8. Специфика этнических миграционных процессов на территории Центральной Сибири в XX-XXI веках: опыт и перспективы : материалы Междунар. науч. конф. (30 ноября - 2 декабря 2017 г.) / отв. за вып. Н. П. Копцева [Электронный ресурс]. - Красноярск : Сиб. федер. ун-т, 2018. - 324 с. - Режим доступа : http://lib3.sfu-kras.ru/ft/LIB2/ELIB/b60/free/i-959917.pdf

9. «Хотим, чтоб мигрантов не было»: Собянин высказался за удорожание трудовых патентов [Электронный ресурс]. - Труд. - 2017. - 25 окт. - Режим доступа : http://www.trud.ru/article/25-10-2017/1355768_.html

\section{Информация об авторе}

Задорин Артем Викторович - магистрант, кафедра всеобщей истории, старший преподаватель, кафедра истории России, Сибирский федеральный университет, 660041, г. Красноярск, пр. Свободный, 82; e-mail: artemzadorin@rambler.ru

\section{Author}

Artem V. Zadorin - Master Student, Chair of Global History, Senior Lecturer, Chair of History of Russia, Siberian Federal University, 82 Svobodnyi avenue, 660041, Krasnoyarsk, Russia; e-mail: artemzadorin@rambler.ru 